\title{
sciendo
}

DOI: $10.2478 /$ rjti-2021-0004

ROMANIAN JOURNAL

OF TRANSPORT INFRASTRUCTURE

\section{CARBONATION RESISTANCE CLASSES OF CONCRETES}

Cristinel Moraru, Drd. Ing, S.C. HeidelbergCement Romania S.A., Bucharest, e-mail: cristinel.moraru@gmail.com

Adelina Apostu, Fiz. Dr., Technical University of Civil Engineering Bucharest, Dan Georgescu, Prof. Dr. Ing., Technical University of Civil Engineering Bucharest

\section{Rezumat}

Carbonatarea betonului este un fenomen care se produce prin pătrunderea în piatra de ciment a $\mathrm{CO}_{2}$ prezent în atmosferă. Fenomenul are loc în prezența apei în care se dizolvă $\mathrm{CO}_{2}$, formând ioni carbonat, care la rândul lor reacționează cu ionii de calciu aflați în porii betonului, rezultând carbonat de calciu (calcită). Difuzia $\mathrm{CO}_{2}$ se produce prin pori și prin defecte de suprafață, acesta pătrunde astfel mai adânc în beton iar reacția de carbonatare se poate produce pe o adâncime mai mare ajungând eventual să depășească grosimea stratului de acoperire producându-se coroziunea armăturilor. [1]

În cazul podurilor din beton armat, coroziunea indusă de carbonatarea betonului reprezintă una din principalele cauze de degradare. Astfel, în etapa de proiectare a structurilor de poduri din beton armat procesul inevitabil de carbonatare a betonului trebuie avut în vedere, în proiectarea durabilităţii, prin calculul grosimii stratului de acoperire cu beton a armăturilor.

Acest articol are ca scop prezentarea conceptului de clasă de rezistenţă la carbonatare, care va reprezenta o schimbare majoră în ceea ce privește standardul pe baza căruia se va stabili grosimea stratului de acoperire cu beton a armaturilor. Această prezentare este efectuată în contextul abordării de performanţă la nivel european a durabilităţii. În acest sens a fost realizată o analiză a rezultatelor experimentale obținute în cadrul unor cercetări efectuate asupra betoanelor preparate cu diferite tipuri de cimenturi, realizate în colaborare $\mathrm{cu}$ colectivul laboratorului Departamentului de Construcții din Beton Armat din cadrul Universității Tehnice de Construcții București. De asemenea, sunt prezentate propuneri de încadrări în clase de rezistenţă la carbonatare pentru betoanele preparate cu două tipuri de cimenturi.

\section{Cuvinte cheie: carbonatare, beton, ciment, durabilitate,}

\section{Abstract}

Concrete carbonation is a phenomenon that occurs by the penetration into the cement stone of $\mathrm{CO}_{2}$ present in the atmosphere. The phenomenon occurs in the presence of water in which $\mathrm{CO}_{2}$ dissolves, forming carbonate ions, which in turn react with calcium ions in the pores of the concrete, resulting in calcium carbonate (calcite). The diffusion of $\mathrm{CO}_{2}$ occurs through pores and surface defects, it thus penetrates deeper into the concrete and the carbonation reaction can occur at a greater depth, eventually exceeding the thickness of the cover, causing corrosion of the reinforcement. [1] 
In the case of reinforced concrete bridges, corrosion induced by carbonation of concrete is one of the main causes of degradation. Thus, in the design stage of the reinforced concrete bridge structures, the inevitable process of carbonation of the concrete must be taken into account, in the design of the durability, by calculating the thickness of the concrete cover layer.

This article aims to present the concept of carbonation resistance class, which will be a major change in the standard based on which the thickness of the concrete cover for reinforcement will be determined. This presentation is made in the context of the European performance approach to durability. In this sense, an analysis of the experimental results obtained in research on concrete prepared with different types of cements, carried out in collaboration with the laboratory of the Reinforced Concrete Structures Department, within the Technical University of Civil Engineering Bucharest. Proposals for classification in the carbonation resistance classes for concretes prepared with two types of cements are also presented.

Keywords: carbonation, concrete, cement, durability,

\section{INTRODUCTION}

The current system for specifying and ensuring the durability of concrete structures is currently based on "deemed to satisfy" rules.

Currently, the durability of concrete is specified by limit values (maximum W/C ratio, minimum cement content, entrained air), cement type (National Annexes). These empirical rules are based on local experience, lacking technical support in terms of "service life". For this reason, there are significant variations between the rules of different European countries.

Given these aspects, as well as the development of a standardization system that allows the determination of important characteristics of durability (carbonation, chloride penetration, freeze-thaw) it was possible to develop a new system for characterizing the concrete durability. This system considers the main parameters of concrete durability design:

$>$ Characterization of exposure conditions,

$>$ Characterization of concrete strength,

$>$ Rules related to resistance to different exposures,

$>$ Requirements related to the minimum thickness of the concrete cover layer of reinforcement, cracking, etc. [2]

The current system for characterizing exposure conditions will be maintained. This is a sufficiently robust system that considers the main mechanisms of concrete damage:

$\checkmark$ Corrosion of fittings due to carbonation, chlorides, 
Damage to the concrete due to the action of freeze-thaw, chemical attacks, etc.

The definition of the environmental resistance class is based on performance. For implementation in practice, the "deemed to satisfy" rule can be used based on objective technical calibrations.

\section{DEFINING CARBONATION RESISTANCE CLASSES}

The definition of the class must be stated based on performance. It must be related to the current system of exposure classes. The requirement for the carbonation resistance class will be related to the XC3 exposure class, while the chloride resistance class will be related to the XS2 exposure class. XC3 "provides" the conditions of a relatively high carbonation rate, and the corrosion conditions are significant. If we consider that the lifetime is defined as the period in which the carbonation is at the level of the reinforcement, the exposure class XC3 presents more severe conditions in terms of carbonation compared to XC4. Higher relative humidity in class $\mathrm{XC} 4$ indicates that in this environment the carbonation rate is lower, but the corrosion rate is higher [2].

For the notion of resistance classes to different types of exposure to be a practical tool, it needs to be supplemented by deemed to satisfy rules, calibrated to different exposure classes.

Based on the definitions of exposure classes, tables should be drawn up (example for carbonation resistance classes - Table 1.) expressing the ability of concretes prepared with certain cements to achieve different classes of resistance to environmental action.

Table 1. Proposal on carbonation resistance classes

\begin{tabular}{|l|c|c|c|c|}
\hline \multirow{2}{*}{ Preliminary values } & \multicolumn{4}{|c|}{ Carbonation resistance classes Rc } \\
\cline { 2 - 5 } & RC20 & RC30 & RC40 & RCX0 \\
\hline $\begin{array}{l}\text { Defining the class, } \\
\text { depth after 50 years [mm] }\end{array}$ & 20 & 30 & 40 & - \\
\hline $\begin{array}{l}\text { Classification in } \\
\text { accordance with standard }\end{array}$ & \multicolumn{4}{|l}{} \\
\hline EN 12390-10 [3] & \multicolumn{4}{|l}{} \\
\hline \multicolumn{1}{|l|}{ CEM I } & & & & \\
\hline CEM II A & & & & \\
\hline CEM II B & & & & \\
\hline
\end{tabular}

Legend: The purpose of this table is to supplement the values of the water/cement ratios considered satisfactory. 
The practical application for classification in certain exposure classes requires, first, the performance of standardized experimental tests. Most of these European standards are developed in an almost final form, already developed or in the process of being developed.

Thus, for the determination of the carbonation depth, the European standard is applied, SR EN 12390-10: 2019 [3]. This standard presents methods for determining the depth of carbonation, either under controlled conditions or in a natural environment. The natural place of exposure must be in an external environment, free from direct precipitation, but allowing an exchange of air. The location must be chosen so that the samples are not subjected to exhaust gases from air conditioning, heating or ventilation ducts or other systems.

The following are some examples of proposals made by experts of the Technical Committee regarding the chapter on sustainability at the level of standard EN 1992-1-1. [4]

Table 2. Proposal to define the carbonation resistance class

\begin{tabular}{|c|c|c|c|c|}
\hline \multirow[t]{2}{*}{ Parameter } & \multicolumn{4}{|c|}{ Carbonation resistance classes } \\
\hline & $\begin{array}{l}\text { RC1 } \\
\text { (very high } \\
\text { resistance) }\end{array}$ & $\begin{array}{l}\mathbf{R C 3} \\
\text { (high } \\
\text { resistance) }\end{array}$ & $\begin{array}{l}\text { RC5 } \\
\text { (medium } \\
\text { resistance) }\end{array}$ & $\begin{array}{l}\text { RC7 } \\
\text { (low } \\
\text { resistance) }\end{array}$ \\
\hline $\begin{array}{l}50 \% \text { - proportion of } \\
\text { carbonation rate } \\
\mathrm{k}_{\mathrm{N}}\left[\mathrm{mm} / \mathrm{year}^{0,5}\right]\end{array}$ & 1 & 3 & 5 & 7 \\
\hline $\begin{array}{l}90 \% \text { - proportion of } \\
\text { carbonation rate } \\
\mathrm{k}_{\mathrm{N}, 90 \%\left[\mathrm{~mm} / \text { year }^{0,5}\right]}\end{array}$ & 2.4 & 4.4 & 6.4 & 8.4 \\
\hline $\begin{array}{l}\text { Standard deviation } \\
\text { of carbonation rate } \\
\mathrm{k}_{\mathrm{N}, \sigma}\left[\mathrm{mm} / \text { year }^{0,5}\right]\end{array}$ & \multicolumn{4}{|c|}{1.1} \\
\hline
\end{tabular}

Below are variants to complete EN 206 and EN 1992-1-1 (the numbering of the chapters and tables proposed to be introduced in the standard will be kept).

\section{Proposals to complete EN 206}

There is a text proposal for EN 206 [5], a supplement to chap. 4.2. Resistance classes with the following articles: 
ROMANIAN JOURNAL

OF TRANSPORT INFRASTRUCTURE

Cristinel Moraru, Adelina Apostu, Dan Georgescu

Carbonation resistance classes of concretes

Concrete can be documented for different classes shown in Table 2 of EN 206 by testing in accordance with the standards presented and the limit values shown in Table 3 of EN 206.

Table 3. (Extract from table 3 of EN 206) Carbonation resistance classes, limit values and applicable standards [5]

\begin{tabular}{|l|c|c|c|}
\hline & \multicolumn{3}{|c|}{ Carbonation resistance classes RXC } \\
\hline & RXC20 & RXC30 & RXC40 \\
\hline $\begin{array}{l}\text { Estimated limit values } \\
\text { after } 50 \text { years } \\
{[\mathrm{mm}] \text { or }\left[\mathrm{kg} / \mathrm{m}^{2}\right]}\end{array}$ & 20 & 30 & 40 \\
\hline Applicable standards & \multicolumn{3}{|c|}{ SR EN 12390-10/12 } \\
\hline
\end{tabular}

Concrete can be a test alternative by applying the "deemed to satisfy" values in Annex $\mathrm{F}$ for different types of cements, water / binder ratios and minimum binder dosages.

The proposal to complete Annex F of EN 206 is presented below.

Table 4. (Extract from table F1 of EN 206) Resistance classes; values considered satisfactory for different binder compositions

(e.g. preliminary values) [5]

\begin{tabular}{|l|c|c|c|}
\hline $\begin{array}{l}\text { Attempt - } \\
\text { Preliminary Values }\end{array}$ & \multicolumn{3}{|c|}{ Carbonation resistance classes RXC } \\
\hline $\begin{array}{l}\text { Type of cement or } \\
\text { equivalent binder } \\
\text { combination }\end{array}$ & $\begin{array}{l}\text { Maximum water/binder ratio } \\
\text { The binder sums up the amount of cement and } \\
\text { concrete additives, within the limits defined } \\
\text { according to EN 206 }\end{array}$ \\
\hline CEM I & 0,55 & 0,60 & 0,65 \\
\hline CEM II-A & 0,45 & 0,55 & 0,65 \\
\hline CEM II-B & 0,40 & 0,50 & 0,60 \\
\hline CEM III-A & NA & 0,45 & 0,55 \\
\hline CEM III-B & NA & NA & 0,45 \\
\hline $\begin{array}{l}\text { Minimum binder } \\
\text { content }\left[\mathrm{kg} / \mathrm{m}^{3}\right]\end{array}$ & 280 & 280 & 280 \\
\hline $\begin{array}{l}\text { NA assumes that no values considered satisfactory for this binder combination and the } \\
\text { specified strength class are defined. }\end{array}$ &
\end{tabular}


ROMANIAN JOURNAL

OF TRANSPORT INFRASTRUCTURE

Cristinel Moraru, Adelina Apostu, Dan Georgescu

Carbonation resistance classes of concretes

\section{Proposals to complete EN 1992-1-1}

There is a proposal to supplement EN 1992-1-1 with Table 4.4 in terms of minimum carbonation depth $\mathrm{c}_{\mathrm{min}}$, dur by lifetime, exposure class and exposure resistance class. [5]

Table 5. (Extract from table 4.4 of EN 1992-1-1) - Minimum concrete cover, $\mathrm{c}_{\mathrm{min} \text {, dur }}$ depending on designed service life, exposure classes and exposure resistance classes [5]

\begin{tabular}{|c|c|c|c|c|c|c|}
\hline \multirow{3}{*}{$\begin{array}{l}\text { Preliminary } \\
\text { Values } \\
\text { Exposure } \\
\text { class - EC } \\
\end{array}$} & \multicolumn{6}{|c|}{$\begin{array}{l}\text { Minimum cover for the projected service life of } 50 \text { and } 100 \text { years } \\
\text { (preliminary values, the values are rounded to } 5 \mathrm{~mm} \text { ) }\end{array}$} \\
\hline & \multicolumn{2}{|c|}{$\mathrm{RXC20}^{2}$} & \multicolumn{2}{|c|}{$\mathrm{RXC30}^{2}$} & \multicolumn{2}{|c|}{$\mathrm{RXC40}^{2}$} \\
\hline & 50 years & 100 years & 50 years & 100 years & 50 years & 100 years \\
\hline $\mathrm{XC1}$ & 10 & 15 & 10 & 20 & 10 & 20 \\
\hline $\mathrm{XC2}$ & 10 & 15 & 15 & 20 & 20 & 30 \\
\hline $\mathrm{XC3}$ & 15 & 20 & 20 & 25 & 25 & 35 \\
\hline $\mathrm{XC4}$ & 15 & 20 & 20 & 25 & 25 & 35 \\
\hline
\end{tabular}

A similar proposal to supplement EC2 is also presented in [7], namely: 
ROMANIAN JOURNAL

OF TRANSPORT INFRASTRUCTURE

Cristinel Moraru, Adelina Apostu, Dan Georgescu

Carbonation resistance classes of concretes

Table 6. Minimum concrete cover (recommended values) for different combinations of exposure classes, strength classes and projected service life (examples, preliminary values)

\begin{tabular}{|c|c|c|c|c|c|c|c|c|}
\hline \multirow{2}{*}{\multicolumn{2}{|c|}{$\begin{array}{l}\text { Preliminary } \\
\text { Values } \\
\text { Exposure } \\
\text { class - EC } \\
\end{array}$}} & \multicolumn{7}{|c|}{$\begin{array}{l}\text { Minimum cover for the projected service life of } 50,100 \text { and } 200 \\
\text { years, recommended values (preliminary) }\end{array}$} \\
\hline & & \multicolumn{3}{|c|}{$\operatorname{RC20}(\mathrm{RCH})^{2}$} & \multicolumn{2}{|c|}{$\operatorname{RC30}(\mathrm{RCH})^{2}$} & \multicolumn{2}{|c|}{$\mathrm{RC} 40(\mathrm{RCH})^{2}$} \\
\hline & $(\mathrm{S} 4)^{3}$ & 50 & 100 & $200(?)$ & 50 & 100 & 50 & 100 \\
\hline $\mathrm{X} 0^{1}$ & $(10)$ & $\mathrm{C}_{\min , \mathrm{b}}$ & $\overline{C_{\min , \mathrm{b}}}$ & $\mathrm{C}_{\min , \mathrm{b}}$ & $\overline{\mathrm{C}_{\min , \mathrm{b}}}$ & $\mathrm{C}_{\min , \mathrm{b}}$ & $\overline{\mathrm{C}_{\min , \mathrm{b}}}$ & $\overline{C_{\min , b}}$ \\
\hline $\mathrm{XC1}$ & $(15$ & 10 & 15 & 20 & 10 & 20 & 10 & 20 \\
\hline $\mathrm{XC2}$ & $(25)$ & 15 & 20 & 30 & 20 & 30 & 25 & 35 \\
\hline $\mathrm{XC3}$ & $(25)$ & 15 & 20 & 30 & 20 & 30 & 25 & 35 \\
\hline $\mathrm{XC4}$ & (30) & 15 & 20 & 30 & 20 & 30 & 25 & 35 \\
\hline $\begin{array}{l}1 \text { In the } \\
\text { Minim } \\
2 \text { On th } \\
\text { in RC3 }\end{array}$ & $\begin{array}{l}\text { exposur } \\
\text { m cover }\end{array}$ & $\begin{array}{l}\text { class X0 } \\
\text { min,b }\end{array}$ & concrete & the carb & tion resis & ce class & $\mathrm{X} 0$ can & $\begin{array}{l}\mathrm{sed} \\
10 \mathrm{~mm}\end{array}$ \\
\hline
\end{tabular}

In conclusion, there are still discussions/variants related to the application/classification of resistance classes to different environmental actions, but obviously determining the performance of concrete in different environmental actions, applying unified European standards, is a necessary and essential condition that can characterize the concrete, regardless of the final version.

\section{EXPERIMENTAL RESEARCH}

This chapter presents the results obtained for concretes prepared with CEM II/A-S 32.5R noted CEM 1 and CEM II/A-M (S-LL) 32.5R noted CEM 2.

With these types of cements were prepared concretes with cement dosages between 280 and $470 \mathrm{~kg} / \mathrm{m}^{3}$, sorts of aggregates $0-4 \mathrm{~mm}(35 \%), 4-8 \mathrm{~mm}(15 \%), 8$ $16 \mathrm{~mm}(21 \%)$ and $16-32 \mathrm{~mm}(29 \%)$ and superplasticizer additive (dinaphthylmethane-sulfonate basic substance)/ hyperplasticizer (polycarboxylate basic substance) according to the experimental research program. The preparation and experimental research carried out on the concrete was done in accordance with the regulations in effect at the time of the research. 
During the research program, the compressive strengths were determined, and the carbonation depths of the concretes prepared with the two types of cements were measured up to the age of 1 year.

The measurements of the average carbonation depth were performed (according to SR EN 14630: 2007) [7], the samples being kept for 7 days in water, then in standardized laboratory conditions (humidity $65 \%$, temperature $20^{\circ} \mathrm{C}$, natural concentration of $\mathrm{CO}_{2}$ ) until the test age. With the help of these values, the carbonation rates and implicitly the size of the concrete covering layer of the reinforcement could be calculated.

The practical application for classification in certain exposure classes requires, first, the performance of standardized experimental tests. For the determination of the carbonation depth the European standard is applied, SR EN 12390-10: 2019. [3]

According to this standard, tests are required at least at intervals of 3, 6 and 12 months, and if the carbonation depth is less than $5 \mathrm{~mm}$, the test duration must be extended to 2 years. This situation occurs if the humidity is higher than $65 \%$, i.e., to maintain the samples in the natural environment (which has the disadvantage that it requires daily monitoring of temperature and humidity).

The determination of the carbonation speed is done by determining the slope of the line obtained by drawing a line through the coordinate points $y$ (carbonation depth) and $\mathrm{x}$ (square root of time). Alternatively, the carbonation rate for each test can be determined by applying the relation:

$$
X_{c}=K_{c} \sqrt{t}
$$

where:

$\mathrm{X}_{\mathrm{c}}=$ average carbonation dept, in $\mathrm{mm}$

$\mathrm{K}_{\mathrm{c}}=$ carbonation rate, in $\mathrm{mm} /$ year $^{0.5}$

$\mathrm{t}=$ actual time, in years

To determine the carbonation rate the effective time is used, that is the time the concrete has been in the carbonation chamber under controlled conditions or in the natural exposure environment. The average carbonation depth measured for each effective time is represented (y-axis) relative to the square root of the effective time in years (x-axis) and a linear regression is represented by points. The slope of the linear regression is the carbonation rate in $\mathrm{mm} / \sqrt{\text { year. }}$

Knowing the slope of the line ( $\mathrm{k}_{\mathrm{c}}$ coefficient) can be determined later the carbonation depth at 50 years, that is the classification in carbonation resistance classes. 
ROMANIAN JOURNAL

OF TRANSPORT INFRASTRUCTURE

Cristinel Moraru, Adelina Apostu, Dan Georgescu

Carbonation resistance classes of concretes

Tables 7 and 8 and the following figures show the results obtained regarding the evolution of the carbonation depth, as well as the processing of the results in order to determine the value of $\mathrm{k}_{\mathrm{c}}$ (carbonation rate) for CEM II/AS 32.5R cement (CEM 1), at different values of the $\mathrm{W} / \mathrm{C}$ ratio, samples kept in water for 7 days and then, until the test age, under standardized conditions of temperature and humidity.

The methodology is applied using carbonation speed results calculated for samples maintained in the carbonation chamber with controlled conditions of temperature, humidity and $\mathrm{CO} 2$ or in the outdoor environment, according to SR EN 12390-10. [3] In the present case, a carbonation resistance class exercise is performed for samples maintained under standardized laboratory conditions. National and international studies have shown that the values of carbonation depths for samples kept indoors are higher than those kept outdoors.

Table 7. Evolution of carbonation depth for CEM 1 cement

\begin{tabular}{|c|c|c|c|c|c|}
\hline \multirow{2}{*}{$\begin{array}{c}\text { Dosage } \\
{\left[\mathrm{kg} / \mathrm{m}^{3}\right]}\end{array}$} & \multirow{2}{*}{$\mathbf{W} / \mathbf{C}$} & \multirow{2}{*}{$\begin{array}{c}\text { Compressive } \\
\text { strength, } 28 \\
\text { days }\left[\mathbf{N} / \mathbf{m m}^{2}\right]\end{array}$} & \multicolumn{3}{|c|}{ Carbonation depth (mm) } \\
\hline & & & 90 days & 180 days & 1 year \\
\hline 260 & 0,61 & 25,03 & 2,96 & 4,64 & 6,34 \\
\hline 280 & 0,59 & 30,66 & 2,27 & 3,23 & 5,68 \\
\hline 300 & 0,54 & 32,72 & 0,91 & 3,11 & 5,24 \\
\hline 320 & 0,50 & 37,12 & 0,63 & 2,17 & 4,25 \\
\hline 340 & 0,48 & 37,96 & 0,50 & 1,73 & 3,54 \\
\hline 370 & 0,45 & 41,15 & 0,49 & 1,70 & 3,33 \\
\hline 400 & 0,40 & 41,60 & 0,49 & 1,23 & 2,43 \\
\hline 470 & 0,36 & 56,27 & 0,40 & 1,14 & 2,11 \\
\hline
\end{tabular}

Figure 1 shows the evolution of the carbonation depth from the term of 28 days when the measurements started, up to the age of 365 days, for different $\mathrm{W} /$ $\mathrm{C}$ ratios - CEM 1. 
ROMANIAN JOURNAL

OF TRANSPORT INFRASTRUCTURE

Cristinel Moraru, Adelina Apostu, Dan Georgescu

Carbonation resistance classes of concretes

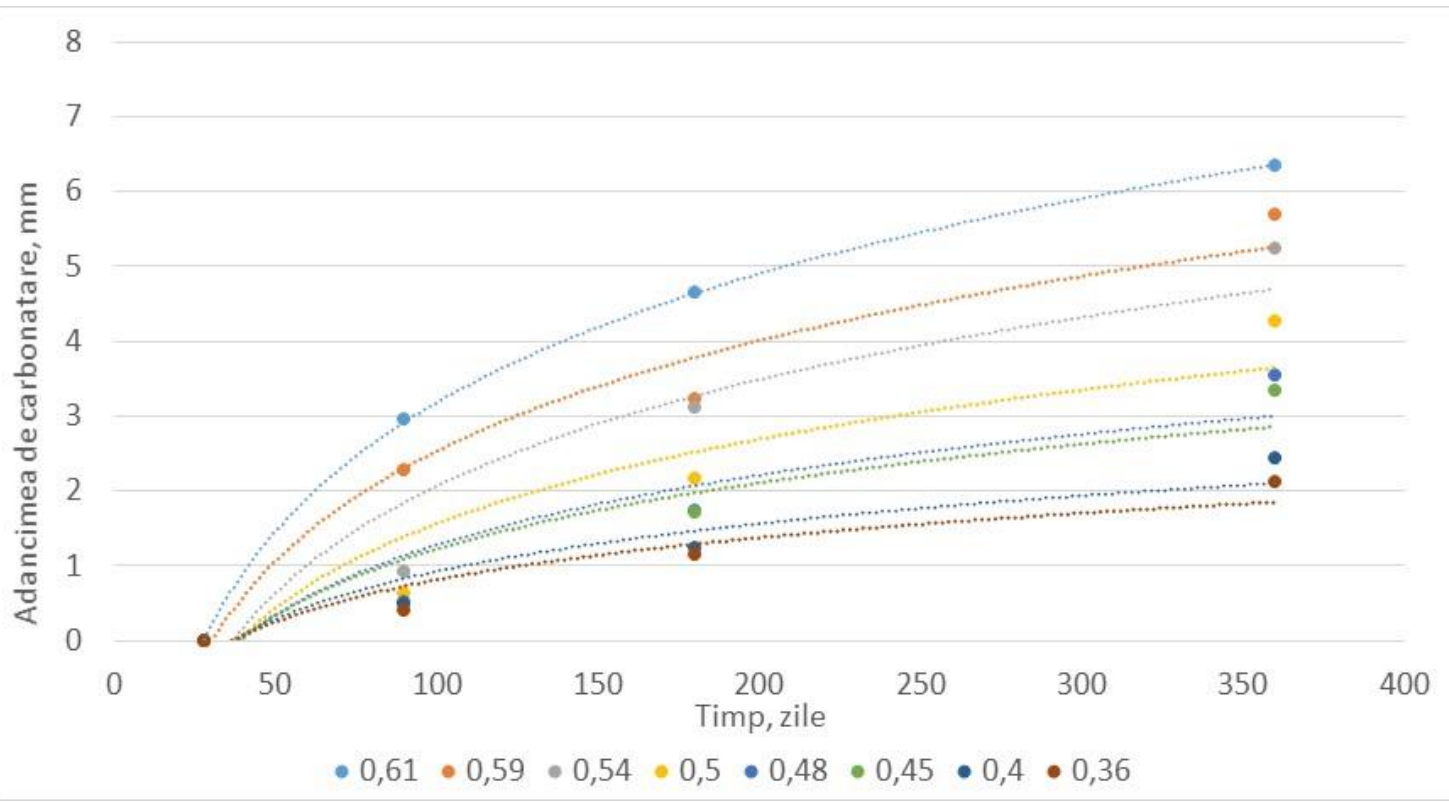

Figure 1. The evolution of the carbonation depth over time - CEM 1

The determination of the carbonation speed is done by finding out the slope of the line obtained by drawing a line through the coordinate points y (carbonation depth) and $x$ (square root of time).

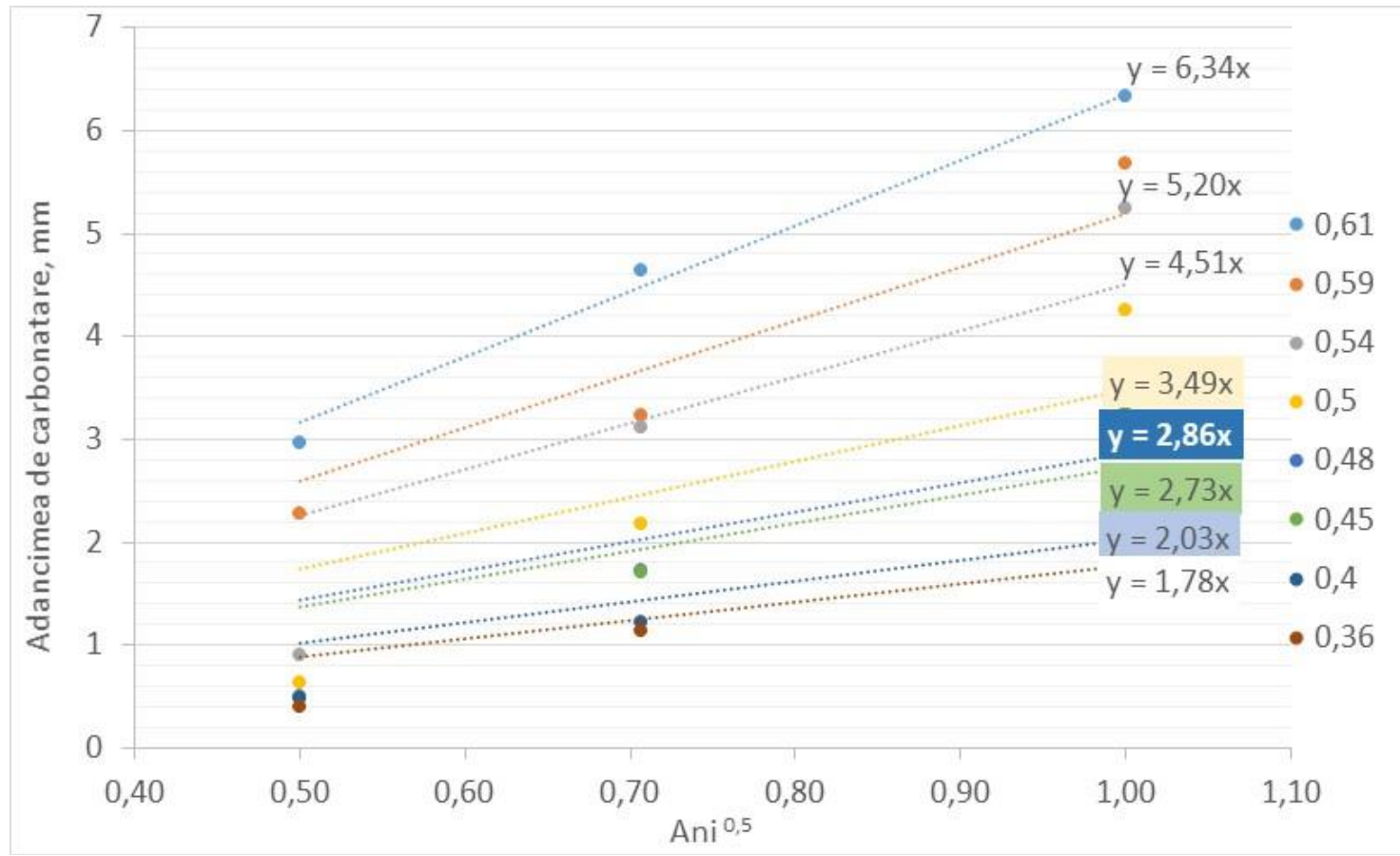

Figure 2. Variation of carbonation depth as a function of square root of time - CEM 1 
ROMANIAN JOURNAL

OF TRANSPORT INFRASTRUCTURE

Cristinel Moraru, Adelina Apostu, Dan Georgescu

Carbonation resistance classes of concretes

Knowing the coefficient $\mathrm{k}_{\mathrm{c}}$, the carbonation depth can be determined for 50 or 100 years, meaning the classification in carbonation resistance classes.

Table 8 presents the values of the carbonation depth at 50 years calculated according to the values of $\mathrm{k}_{\mathrm{c}}$ and a proposal for classification in carbonation resistance classes for this type of cement.

It needs to be mentioned that that the values presented in Table 8 have an example character of application of the methodology because the values of $\mathrm{k}_{\mathrm{c}}$ were not determined experimentally in the conditions given by SR EN 12390-10: 2019. [3]

Table 8. Carbonation depth values at 50 years calculated according to kc values and proposal for classification in carbonation resistance classes - CEM 1

\begin{tabular}{|c|c|c|c|}
\hline $\mathbf{W} / \mathbf{C}$ & $\begin{array}{c}\mathbf{K}_{\mathbf{c}}, \\
{\left[\mathbf{m m} / \mathbf{a}^{\mathbf{0}, \mathbf{5}}\right]}\end{array}$ & $\begin{array}{c}\mathbf{X C}, \\
\mathbf{m m} / \mathbf{5 0} \text { years }\end{array}$ & $\mathbf{R X C}$ \\
\hline 0,61 & 6,34 & $\mathbf{4 4 , 8 3}$ & $\mathbf{R X C 5 0}$ \\
\hline 0,59 & 5,20 & $\mathbf{3 6 , 7 7}$ & $\mathbf{R X C 4 0}$ \\
\hline 0,54 & 4,51 & $\mathbf{3 1 , 8 9}$ & $\mathbf{R X C 4 0}$ \\
\hline 0,50 & 3,49 & $\mathbf{2 4 , 6 8}$ & $\mathbf{R X C 3 0}$ \\
\hline 0,48 & 2,86 & $\mathbf{2 0 , 2 2}$ & $\mathbf{R X C 3 0}$ \\
\hline 0,45 & 2,73 & $\mathbf{1 9 , 3 0}$ & $\mathbf{R X C 2 0}$ \\
\hline 0,40 & 2,03 & $\mathbf{1 4 , 3 5}$ & $\mathbf{R X C 2 0}$ \\
\hline 0,36 & 1,78 & $\mathbf{1 2 , 5 9}$ & $\mathbf{R X C 2 0}$ \\
\hline
\end{tabular}
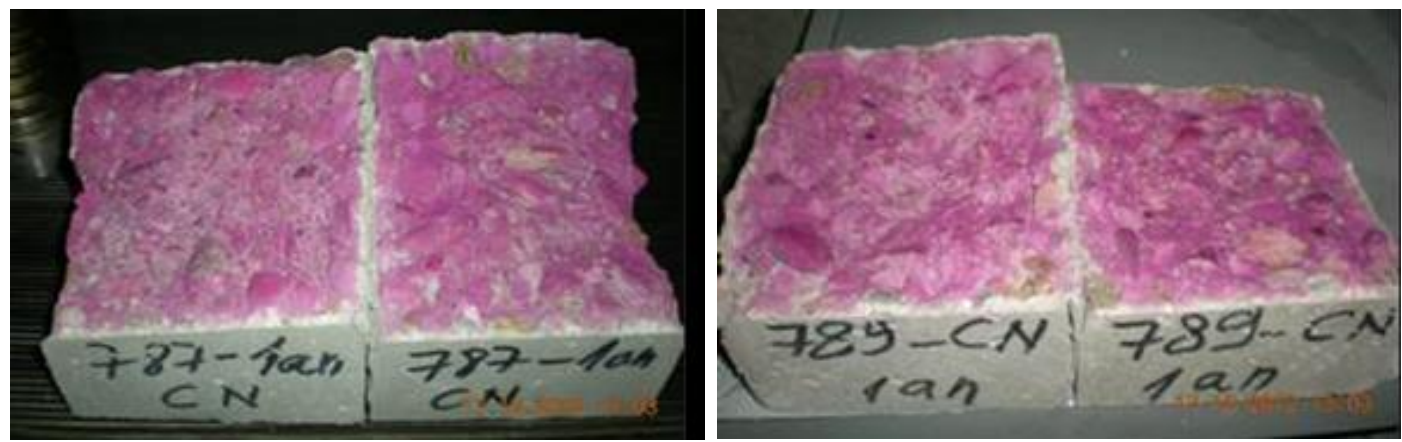
ROMANIAN JOURNAL

OF TRANSPORT INFRASTRUCTURE

Cristinel Moraru, Adelina Apostu, Dan Georgescu

Carbonation resistance classes of concretes

A similar approach is presented for the CEM II/A-M (S-LL) 32.5R cement - CEM 2. For this assortment of cement there were available results up to 2 years which were used for the calculation of $\mathrm{K}_{\mathrm{c}}$ with superior accuracy.

Table 9. Evolution of carbonation depth for CEM 2 cement

\begin{tabular}{|c|c|c|c|c|c|c|}
\hline \multirow{2}{*}{$\begin{array}{c}\text { Dosage } \\
{\left[\mathrm{kg} / \mathrm{m}^{3}\right.} \\
]\end{array}$} & \multirow{2}{*}{$\mathbf{W} / \mathbf{C}$} & \multirow{2}{*}{$\begin{array}{l}\text { Compressive } \\
\text { strength, } 28 \\
\text { days }\left[\mathrm{N} / \mathbf{m m}^{2}\right]\end{array}$} & \multicolumn{4}{|c|}{ Carbonation depth (mm) } \\
\hline & & & 90 days & 180 days & 1 year & 2 years \\
\hline 280 & 0,61 & 30,67 & 3,53 & 4,43 & 5,83 & 11,01 \\
\hline 320 & 0,49 & 47 & 2,99 & 4,17 & 5,41 & 8,34 \\
\hline 370 & 0,43 & 42,81 & 0,65 & 3,19 & 4,19 & 4,85 \\
\hline 400 & 0,40 & 46,24 & 0,42 & 2,74 & 3,25 & 4,23 \\
\hline 470 & 0,37 & 49,66 & 0,38 & 1,87 & 2,25 & 3,91 \\
\hline
\end{tabular}

Figure 3 shows the evolution of the carbonation depth from the term of 28 days when the measurements started, up to the final term, for different $\mathrm{W} / \mathrm{C}$ ratios - CEM 2.

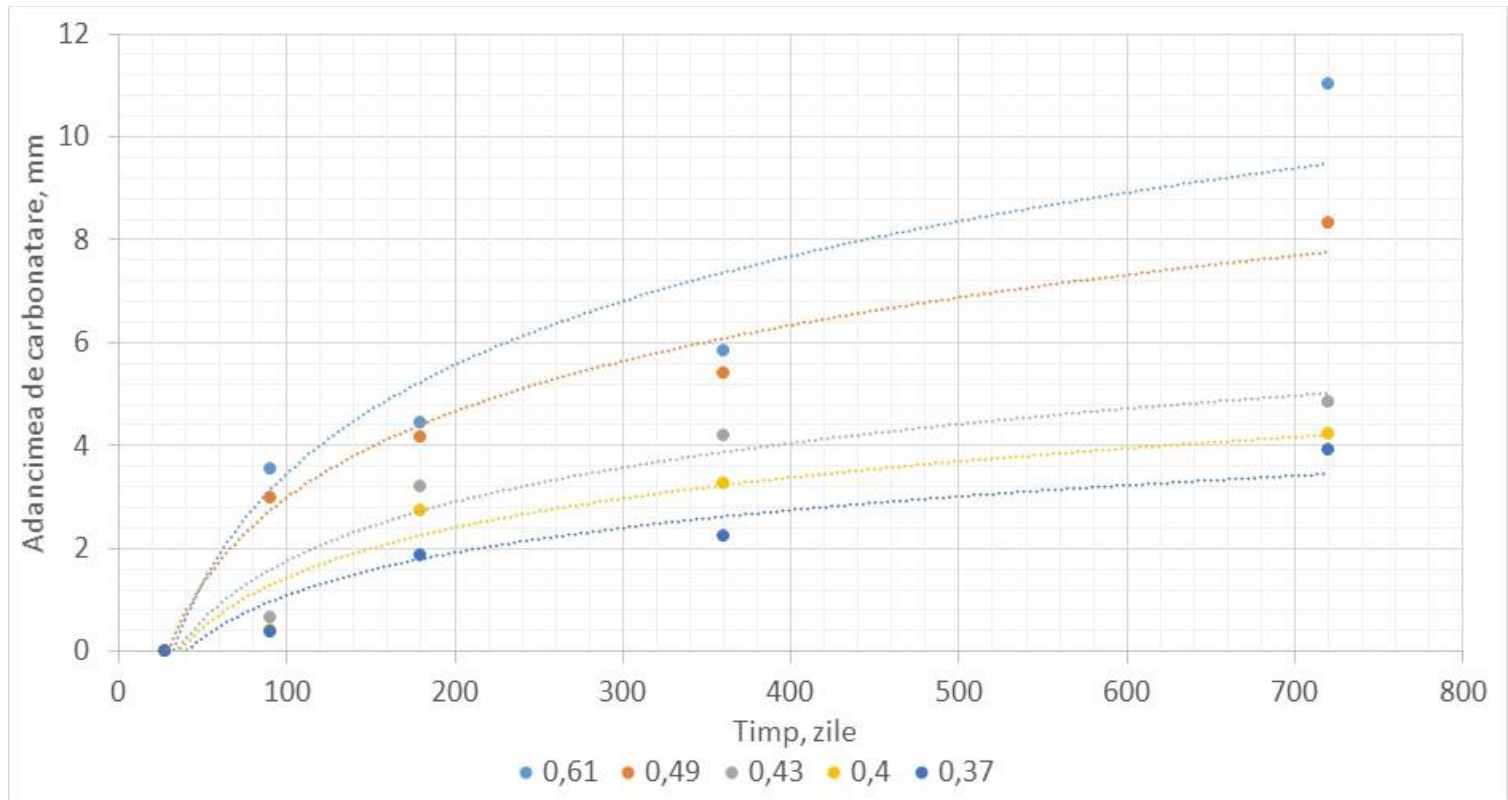

Figure 3. The evolution of the carbonation depth over time - CEM 2 
ROMANIAN JOURNAL

OF TRANSPORT INFRASTRUCTURE

Cristinel Moraru, Adelina Apostu, Dan Georgescu

Carbonation resistance classes of concretes

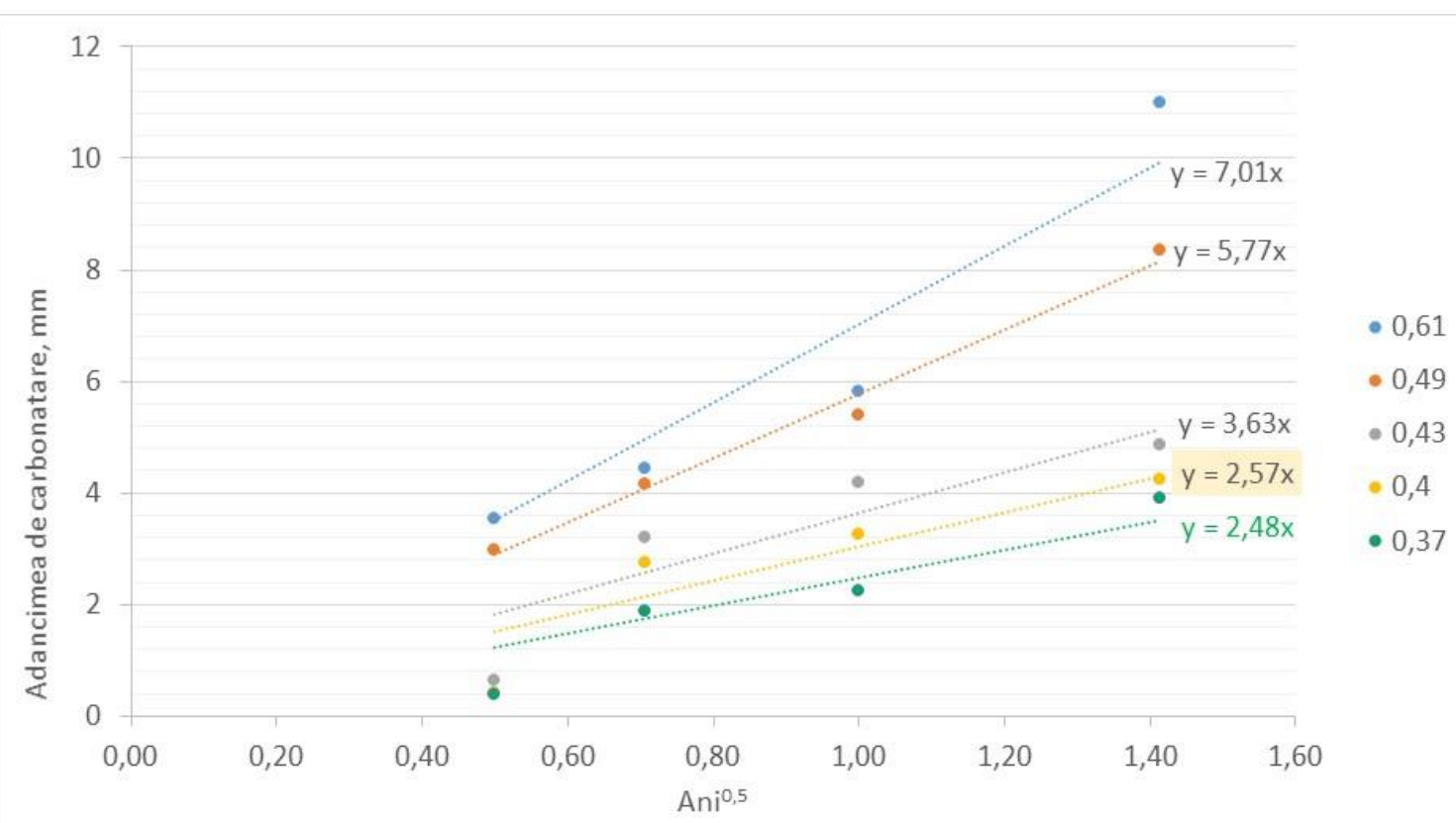

Figure 4. Variation of carbonation depth as a function of square root of time - CEM 2

The values of the carbonation rate according to the $\mathrm{W} / \mathrm{C}$ ratio, the carbonation depth at 50 years and the proposal for classification in carbonation resistance classes are presented in Table 10.

Table 10. Carbonation depth values at 50 years calculated according to kc values and proposal for classification in carbonation resistance classes - CEM 2

\begin{tabular}{|c|c|c|c|}
\hline $\mathbf{W} / \mathbf{C}$ & $\begin{array}{c}\mathbf{K}_{\mathbf{c}}, \\
{\left[\mathbf{m m} / \mathbf{a}^{\mathbf{0} 5}\right]}\end{array}$ & $\begin{array}{c}\mathbf{X C}, \\
{[\mathbf{m m} / \mathbf{5 0} \text { years }]}\end{array}$ & $\mathbf{R X C}$ \\
\hline 0,61 & 7,01 & $\mathbf{4 9 , 5 7}$ & $\mathbf{R X C 5 0}$ \\
\hline 0,49 & 5,77 & $\mathbf{4 0 , 8 0}$ & $\mathbf{R X C ~ 4 0 *}$ \\
\hline 0,43 & 3,63 & $\mathbf{2 5 , 6 7}$ & $\mathbf{R X C 3 0}$ \\
\hline 0,40 & 2,57 & $\mathbf{1 8 , 1 7}$ & $\mathbf{R X C 2 0}$ \\
\hline 0,37 & 2,48 & $\mathbf{1 7 , 5 4}$ & RXC20 \\
\hline
\end{tabular}

*) The carbonation resistance class RXC40 was considered given the value quite close to 40 . In this case additional tests must be performed to determine the exact value of the carbonation depth.

The capacity of concretes prepared with the two types of cements to achieve different classes of carbonation resistance are presented in Tables 11 and 12. 
Table 11. Proposal for classification into 4 classes of carbonation resistance for concretes prepared with the cements studied

\begin{tabular}{|l|c|c|c|c|}
\hline \multirow{2}{*}{ Preliminary values } & \multicolumn{4}{|c|}{ RXC carbonation resistance classes } \\
\cline { 2 - 5 } & RXC20 & RXC30 & RXC40 & RXC50 \\
\hline $\begin{array}{l}\text { Defining the class, } \\
\text { depth after 50 years [mm] }\end{array}$ & 20 & 30 & 40 & 50 \\
\hline Prescriptive criterion & \multicolumn{5}{|c|}{ Maximum W / C ratio } \\
\hline CEM II/A-S 32,5R - CEM 1 & 0,45 & 0,50 & 0,59 & 0,61 \\
\hline CEM II/A-M(S-LL) 32,5R - CEM 2 & 0,40 & 0,43 & 0,49 & 0,61 \\
\hline Minimum binder content [kg/m $\left.{ }^{3}\right]$ & 280 & 280 & 280 & 280 \\
\hline
\end{tabular}

Table 12 proposes a similar approach but with a higher accuracy compared to the previous version. The accuracy is conferred by the carbonation rate criterion $\mathrm{K}_{\mathrm{c}}$.

Table 12. Proposal to classify into 6 carbonation resistance classes

\begin{tabular}{|l|c|c|c|c|c|c|}
\hline Classes & RC2 & RC3 & RC4 & RC5 & RC6 & RC7 \\
\hline $\mathrm{K}_{\mathrm{c}}$ range $\left[\mathrm{mm} / \mathrm{a}^{0,5}\right]$ & $1<\mathrm{K}_{\mathrm{c}} \leq 2$ & $2<\mathrm{K}_{\mathrm{c}} \leq 3$ & $3<\mathrm{K}_{\mathrm{c}} \leq 4$ & $4<\mathrm{K}_{\mathrm{c}} \leq 5$ & $5<\mathrm{K}_{\mathrm{c}} \leq 6$ & $6<\mathrm{K}_{\mathrm{c}} \leq 7$ \\
\hline $\begin{array}{l}\mathrm{K}_{\mathrm{c}}\left[\mathrm{mm} / \mathrm{a}^{0,5}\right] \\
\text { Cement type }\end{array}$ & 2 & 3 & 4 & 5 & 6 & 7 \\
\hline $\begin{array}{c}\text { CEM II/A-S 32,5R } \\
- \text { CEM 1 }\end{array}$ & 0,40 & 0,48 & 0,50 & 0,54 & 0,59 & 0,61 \\
\hline $\begin{array}{c}\text { CEM II/A-M(S- } \\
\text { LL) 32,5R - CEM 2 }\end{array}$ & - & 0,4 & 0,43 & - & 0,49 & 0,61 \\
\hline
\end{tabular}

To determine the minimum concrete cover values for reinforcement, according to the carbonation resistance classes and the $\mathrm{W} / \mathrm{C}$ ratios (see table 6) and taking into account table 12, values can be proposed according to tables 13 , 14 for each type of cement tested. [11] 
ROMANIAN JOURNAL

OF TRANSPORT INFRASTRUCTURE

Cristinel Moraru, Adelina Apostu, Dan Georgescu

Carbonation resistance classes of concretes

Table 13. Concrete cover according to carbonation resistance class and $\mathrm{W} / \mathrm{C}$ ratio, concretes prepared with CEM 1

\begin{tabular}{|c|c|c|c|c|c|c|c|c|c|}
\hline \multicolumn{10}{|c|}{ CEM II/A-S 32,5R - CEM 1} \\
\hline \multirow{2}{*}{ W / C } & Exposure class & \multicolumn{2}{|c|}{ XC1 } & \multicolumn{2}{|c|}{$\mathrm{XC2}$} & \multicolumn{2}{|c|}{$\mathbf{X C 3}$} & \multicolumn{2}{|c|}{ XC4 } \\
\hline & $\begin{array}{l}\text { Designed service } \\
\text { life [years] }\end{array}$ & 50 & 100 & 50 & 100 & 50 & 100 & 50 & 100 \\
\hline 0,40 & $\mathrm{RC} 2$ & 10 & 15 & 10 & 15 & 15 & 25 & 15 & 25 \\
\hline 0,48 & RC3 & 10 & 15 & 15 & 20 & 20 & 30 & 20 & 30 \\
\hline 0,50 & $\mathrm{RC} 4$ & 10 & 20 & 15 & 25 & 25 & 35 & 25 & 40 \\
\hline 0,54 & $\mathrm{RC5}$ & 15 & 25 & 20 & 30 & 25 & 45 & 30 & 45 \\
\hline 0,59 & RC6 & 15 & 25 & 25 & 35 & 35 & 55 & 40 & 55 \\
\hline 0,61 & $\mathrm{RC7}$ & 15 & 30 & 25 & 40 & 40 & 60 & 45 & 60 \\
\hline
\end{tabular}

Table 14. Concrete cover according to carbonation resistance class and W / C ratio, concretes prepared with CEM 2

\begin{tabular}{|l|l|l|l|l|l|l|l|l|l|}
\hline \multicolumn{10}{|c|}{ CEM II/A-M(S-LL) 32,5R - CEM 2 } \\
\hline \multirow{2}{*}{ W / C } & Exposure class & \multicolumn{2}{|l|}{ XC1 } & \multicolumn{2}{|l|}{ XC2 } & \multicolumn{1}{l|}{ XC3 } & \multicolumn{2}{l|}{ XC4 } \\
\cline { 2 - 11 } & $\begin{array}{l}\text { Designed service } \\
\text { life [years] }\end{array}$ & 50 & 100 & 50 & 100 & 50 & 100 & 50 & $\mathbf{1 0 0}$ \\
\hline 0,40 & RC3 & 10 & 15 & 15 & 20 & 20 & 30 & 20 & $\mathbf{3 0}$ \\
\hline 0,43 & RC4 & 10 & 20 & 15 & 25 & 25 & 35 & 25 & $\mathbf{4 0}$ \\
\hline 0,49 & RC6 & 15 & 25 & 25 & 35 & 35 & 55 & 40 & $\mathbf{5 5}$ \\
\hline 0,61 & RC7 & 15 & 30 & 25 & 40 & 40 & 60 & 45 & $\mathbf{6 0}$ \\
\hline
\end{tabular}

These are examples of possibilities of application of carbonation resistance classes, starting from the studies performed on the prepared concretes with the studied cements. These examples can be compared with international results [9].

Tables 13 and 14 highlight the values of concrete cover for monumental structures such as bridges, depending on the carbonation resistance class (XC4 exposure class, 100 years designed service life). 


\section{CONCLUSIONS}

The design and execution of concrete bridges must consider the requirements of operational safety, ensuring the designed service life, functionality and finally their aesthetic aspect. This article presents general considerations of the methodology and does not indicate the possibility of using these assortments of cement for bridges. Also, in this article was presented a model of application of the methodology, because normally the concrete must be maintained in conditions of constant humidity and concentration to determine the coefficient $\mathrm{k}$, and regarding the influence of humidity on carbonation this aspect appears in Tab. 13 and 14, in which for the same carbonation resistance classes different coating thicknesses result depending on the carbonation classes XC.

Imposing efficient maintenance measures will ensure the durability of concrete structures, representing the optimal option from a technical-economic point of view.

The increase of the concrete class determines the reduction of the carbonation depth values in concretes, decreasing, to some extent, the importance of the type of cement chosen in the preparation of the concretes.

These results highlight the influence of admixtures on the carbonation rate of concrete. From the point of view of the durability characteristics, for the same class of concrete, significant differences were obtained in the case of the carbonation depths of the concretes prepared with the two studied cements. The results obtained can provide indications of possible sensitivities to different types of environmental actions of concrete prepared with different percentages of additives.

From the presented results the close connection between the need to establish the durability / carbonation resistance classes and the calculation of the thickness of concrete cover for reinforcement.

Regardless of the variant that will be chosen for the introduction of carbonation resistance classes in the new rules, for a type of cement, the most unfavorable value obtained from the experimental tests must be considered. Also, carbonation resistance classes and not only, should be proposed depending on the type of cement addition.

Assuming the durability of concrete elements, if restrictions are considered only in terms of the strength class of the concrete, the cement dosage or the water / cement ratio, they may not be sufficient. Similar studies should be made, in the future, for concrete with high mechanical class cement, even if in this case the cement type is not so important. 


\section{ROMANIAN JOURNAL \\ OF TRANSPORT INFRASTRUCTURE}

Cristinel Moraru, Adelina Apostu, Dan Georgescu

Carbonation resistance classes of concretes

It can thus be stated that the experimental research is the only one that offers answers regarding the characteristics of concretes prepared with different types of cements, but also using different compositions.

\section{REFERENCES}

[1]. CIROM, "Studiu documentar preliminar referitor la capacitatea betonului de a fixa dioxidul de carbon atmosferic prin carbonatare si recarbonatare", Aprilie 2009.

[2]. Steinar Leivestad Convenor, "Durability Exposure Resistance Classes, a new system to specify durability in EN 206 and EN 1992, JWG Durability JWG 250/104 - N25”, 2014

[3]. SR EN 12390-10:2019 Încercări pe beton intărit. Partea 10: Determinarea rezistenței la carbonatare a betonului la nivelurile atmosferice de dioxid de carbon,

[4]. SR EN 1992-1-1:2004 Eurocod 2: Proiectarea structurilor de beton; Partea 1-1: Reguli generale and reguli pentru clădiri.

[5]. STEINAR LEIVESTAD - "Durability, Concrete, Environment and Sustainability in the Eurocodes", 02.05.2019, Standard Norge.

[6]. JWG TC104/SC1-TC250/SC2 N26, Exposure resistance classes - draft for proposal on a new system to specify durability in EN 206 and EN 1992, technical background documentation, March 2014

[7]. SR EN 14630:2007 Produse şi sisteme pentru protecţia şi repararea structurilor de beton. Metode de incercări. Determinarea adâncimii de carbonatare în betonul întărit prin metoda cu fenolftaleină.

[8]. FprEN 12390-10:2018 Testing hardened concrete - Part 10: Determination of the carbonation resistance of concrete at atmospheric levels of carbon dioxide.

[9]. SR EN 12390-12:2020 Încercări pe beton întărit. Partea 12: Determinarea rezistenței la carbonatare a betonului. Metodă de carbonatare accelerată,

[10]. Andres Belda Revert, Klaartje De Weerdt, Karla Hornbostel, Mette Rica Geiker, ,State of the art report: Service life modelling carbonation of concrete and corrosion in carbonated concrete R-1-2017", april 2017

[11]. CEN/TC 250/ SC 2/WG 1 N 912 - New ERC Concept, Național Freedom, 